\title{
Relationship between various phases of milk flow at mechanical milking system and the somatic cell count in cow's milk
}

\author{
P. Mijić1,4, I. Knežević ${ }^{1}$, M. Domaćinović ${ }^{1}$, A. Ivanković ${ }^{2}$ and Z. Ivkić \\ ${ }^{I}$ Faculty of Agriculture Osijek \\ Trg sv. Trojstva 3, 31000 Osijek, Croatia \\ ${ }^{2}$ Faculty of Agriculture Zagreb \\ Svetošimunska c. 25, 10000 Zagreb, Croatia \\ ${ }^{3}$ Croatian Livestock Center \\ Ilica 101, 10000 Zagreb, Croatia
}

(Received 8 December 2004; revised version 7 June 2005; accepted 4 August 2005)

\begin{abstract}
For the udder to remain healthy, milking period should be brief, and the optimal milk flow has to be reached as soon as possible and remain constant as long as possible. Research has shown that the lowest somatic cell count (SCC) for the Holstein cows logarithmic sec (LSCC $=3.03$ ) were observed duration of increasing phase (dIP) $=0.3-0.6 \mathrm{~min}$, and in those of the Simmental breed $(\mathrm{LSCC}=2.96)$ at $\mathrm{dIP}=0.6-0.9 \mathrm{~min}$. Furthermore, the prolongation of the plateau phase $(\mathrm{dPP})$ of the milk flow curve have a beneficial effect on the udder health in both breeds of cows (LSCC $=2.46$ and 2.50). The dPP should be prolonged by shortening the duration of decreasing phase (dDP), since the lowest somatic cell counts in milk ( $\mathrm{LSCC}=3.27$ and 2.80) were observed when the dDP was shorter than $0.7 \mathrm{~min}$.
\end{abstract}

KEY WORDS: milk, somatic cell count, machine milking, cow

\section{INTRODUCTION}

With the increased introduction of mechanized milking systems in the dairy production enterprises, a certain discrepancy was observed between the working

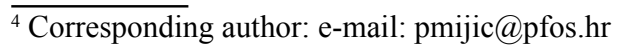


of the milking machines and cows udders. In order to correct that, certain adjustments need to be done, if we are to exploit the maximal efficiency of the milking machine, and ensure the health of the udder. Milk flow is an indicator of the speed of milking at a certain point of the milking process. The rate of flow is determined by the width of the teat canal (Mijic et al., 2003). The width of the teat canal is also closely correlated to the health of the udder. At a fast rate of flow of milk, wide teat canal, and a weak sphincter of the teat, microorganisms easily penetrate the udder and cause infection (Roth et al., 1998). To define the "udder health index", Boettcher et al. (1998) list milk flow and the duration of the milking process, as major determinants that influence udder health. The objectives of this research were to point out how relationships between certain phases of the milk flow during the machine milking and the somatic cell counts in cow's milk may be used as a selection tool to improve the udder health in cattle.

\section{MATERIAL AND METHODS}

\section{Animals}

Milking rate was measured on an agricultural firm total in government own, at the East Croatia. Total number of dairy cows on that firm is 1800 . The research consisted of 457 Holstein and 61 Simmental cows. Only health cows with correct morphological appearance of teats were analysed. Cows treated against mastitis, with udder inflammation, in oestrus, sick, badly hurt or cows exposed to some instantaneous condition which influenced a daily milk quote were not included into research. Before each milking, the udder quarters were washed in lukewarm water, disinfected and wiped up with a dry paper tissue.

\section{Measurements}

Measuring were performed by a mobile Lacto-Corder unit, Ser no. 16842, SW-Version: 93004 (manufacturer WMB AG, CH-9436 Balgach). In 1999 the unit received an international recognition by ICAR (International Committee for Animal Recording) for quantity measuring and milk sample taking by machine milking. Lacto-Corder has a possibility of graphical recording the milk flow curve from first milk flash till the milking end. Following parameters were used:

- the milk quantity per milking, $\mathrm{MQ}, \mathrm{kg}$

- the maximum flow rate, MFR, $\mathrm{kg} / \mathrm{min}$

- the average flow rate, AFR, $\mathrm{kg} / \mathrm{min}$

- the duration of increasing phase, dIP, min 
- the duration of plateau phase, dPP, min - the duration of decreasing phase, $\mathrm{dDP}, \min$

- the duration of main phase, dMP, min.

The milk samples taken by Lacto-Corder were analysed in the Central State Laboratory for milk quality control (Križevci) whereby the somatic cell count was established by Bentley Somacount 500. The milking equipment was checked before every milking and coordinated with the same under pressure values (43$48 \mathrm{kPa})$, pulsation relations $(1: 1)$ and tact numbers $(58-60)$. For each cow one measuring was performed in the period of the $50^{\text {th }}$ to $180^{\text {th }}$ lactation day, whereby the German regulations (ADR, 1987) were used. The measurements of the milking parameters were carried out in early and middle lactation for several reasons: 1. in this part of lactation the highest milk production is achieved, as well as the highest maximum rate of milk flow and the longest total milking time, 2. during this time the variability among the lactation groups is the highest. Finally, the measurements in early and middle lactation should be the most useful as a parameter of foreseeing (Mijić et al., 2003).

\section{Statistics}

To make a normal distribution, the somatic cell count (SCC) in milk was converted into logarithmic (Dodenhoff et al., 1999) by means of a formula (log2 $(\mathrm{SCC} / 100,000)+3)$ and marked as LSCC. This value was further used in statistical procedure. All statistical data analysis were performed in statistical program STATISTICA, version 6 (StatSoft, Inc., 2003). For establishing a linear connection between variables, Pearson's correlation coefficient (PROC CORR) was used.

\section{RESULTS}

The amount of milk per milking was on average $2.84 \mathrm{~kg}$ greater in cows of the Holstein breed compared to the Simmental cows. The rate of flow of milk was similarly faster by $0.77 \mathrm{~kg} / \mathrm{min}$ in Holstein cows, leading to the prolongation of the main milking phase by $0.55 \mathrm{~min}$ (Table 1 ). In both breeds, the longest was the $\mathrm{dDP}$ (4.51 and $3.96 \mathrm{~min})$. The milk of the Simmental cows showed lower somatic cell counts $(\mathrm{LSCC}=3.63)$ compared to the milk of Holstein cows $(\mathrm{LSCC}=3.87)$.

The duration of the dIP milk flow at which the lowest somatic cell count was determined in Holstein cows was between 0.3 and 0.6 min (Figure 1). A slightly longer duration is favoured for Simmental cows, ranging from 0.6 to $0.9 \mathrm{~min}$. Shorter ingoing phases ( $\mathrm{dIP}<0.3 \mathrm{~min})$ had a greater deleterious effect on udder health than longer ones ( $\mathrm{dIP}>0.9 \mathrm{~min})$. Both breeds showed similar trends with 
TABLE 1

Means $(\overline{\mathrm{x}})$ i standard deviations (sd) of milking parameters and mastitis indication

\begin{tabular}{|c|c|c|c|c|c|}
\hline \multirow{2}{*}{ Parameters ${ }^{1}$} & \multirow{2}{*}{ Unit } & \multicolumn{2}{|c|}{$\begin{array}{c}\text { Holstein } \\
\mathrm{n}=457\end{array}$} & \multicolumn{2}{|c|}{$\begin{array}{c}\text { Simmental } \\
\mathrm{n}=61\end{array}$} \\
\hline & & $\bar{x}$ & SD & $\overline{\mathrm{x}}$ & SD \\
\hline MQ & $\mathrm{kg}$ & 10.18 & 3.66 & 7.34 & 2.76 \\
\hline L-Milk & $\mathrm{kg}$ & 6017 & 1056 & 4367 & 684 \\
\hline MFR & $\mathrm{kg} / \mathrm{min}$ & 3.49 & 1.27 & 2.72 & 0.97 \\
\hline AFR & $\mathrm{kg} / \mathrm{min}$ & 2.27 & 0.79 & 1.88 & 0.68 \\
\hline dIP & $\min$ & 0.75 & 0.55 & 0.58 & 0.43 \\
\hline dPP & $\min$ & 1.67 & 1.36 & 1.52 & 1.09 \\
\hline dDP & $\min$ & 2.14 & 1.27 & 1.87 & 1.27 \\
\hline $\mathrm{dMP}$ & $\min$ & 4.51 & 1.88 & 3.96 & 1.45 \\
\hline $\mathrm{SCC}$ & $1.000 / \mathrm{ml}$ & 515 & - & 452 & - \\
\hline LSCC & $10 \mathrm{~g}$ & 3.87 & 0.11 & 3.63 & 0.29 \\
\hline
\end{tabular}

${ }^{1}$ MQ - milk quantity per milking; L-Milk - production in 305-day lactation; MFR - maximum flow rate; AFR - average flow rate; dIP - duration of increasing phase; dPP - duration of plateau phase; dDP - duration of decreasing phase; dMP - duration of main phase; SCC - somatic cell count; LSCC - logarithmic number of the somatic cell counts

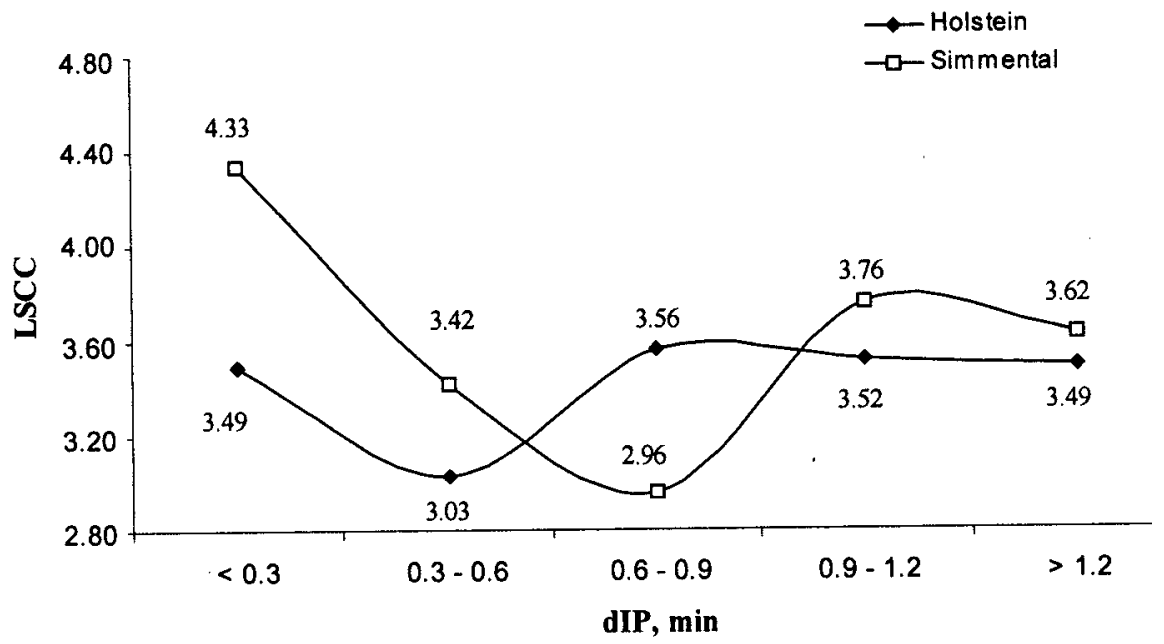

Figure 1. Relations between duration of increasing phase (tIP) and somatic cell count (LSCC) in Holstein and Simmental cows

respect to LSCC and dPP (Figure 2). The plateau phase which ranged from 2.5 to $3.5 \mathrm{~min}$ in Simmental cows, and longer than $3.5 \mathrm{~min}$ in Holstein cows, had the lowest effect on udder health (lowest somatic cell counts in milk). Figure 3 shows that the cows which had the dDP $<2.1$, also had the lowest LSCC, while the prolongation of $\mathrm{dDP}(>2.1 \mathrm{~min})$ caused an increase in the value of LSCC. 


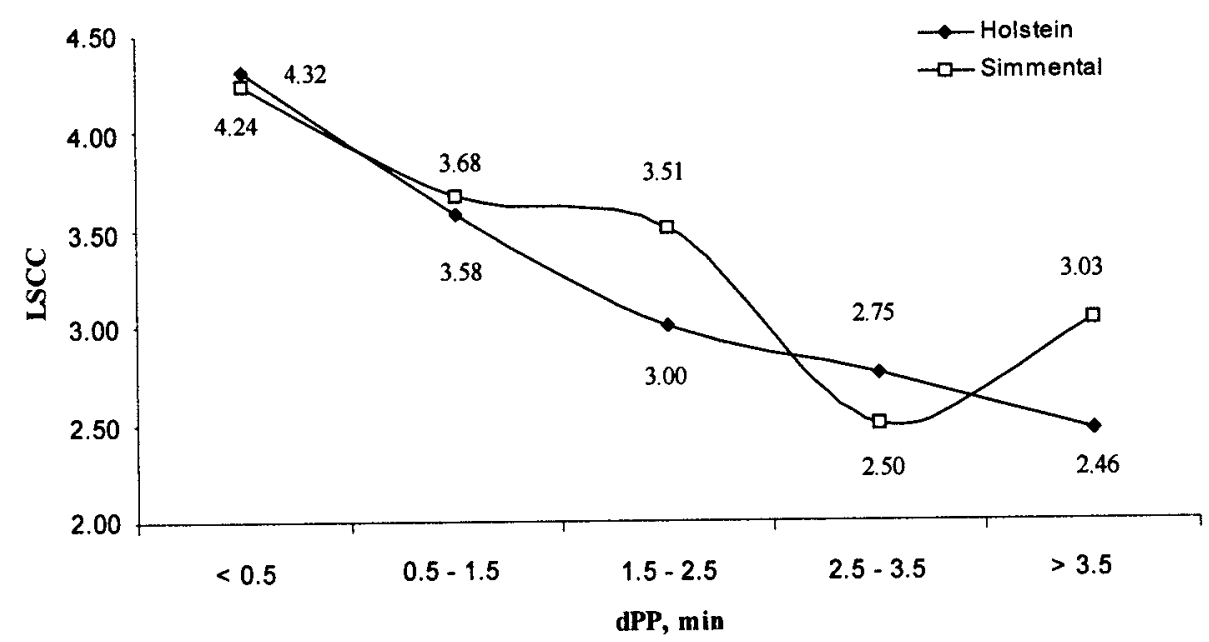

Figure 2. Relations between duration of plateau phase (dPP) and somatic cell count (LSCC) in Holstein and Simmental cows

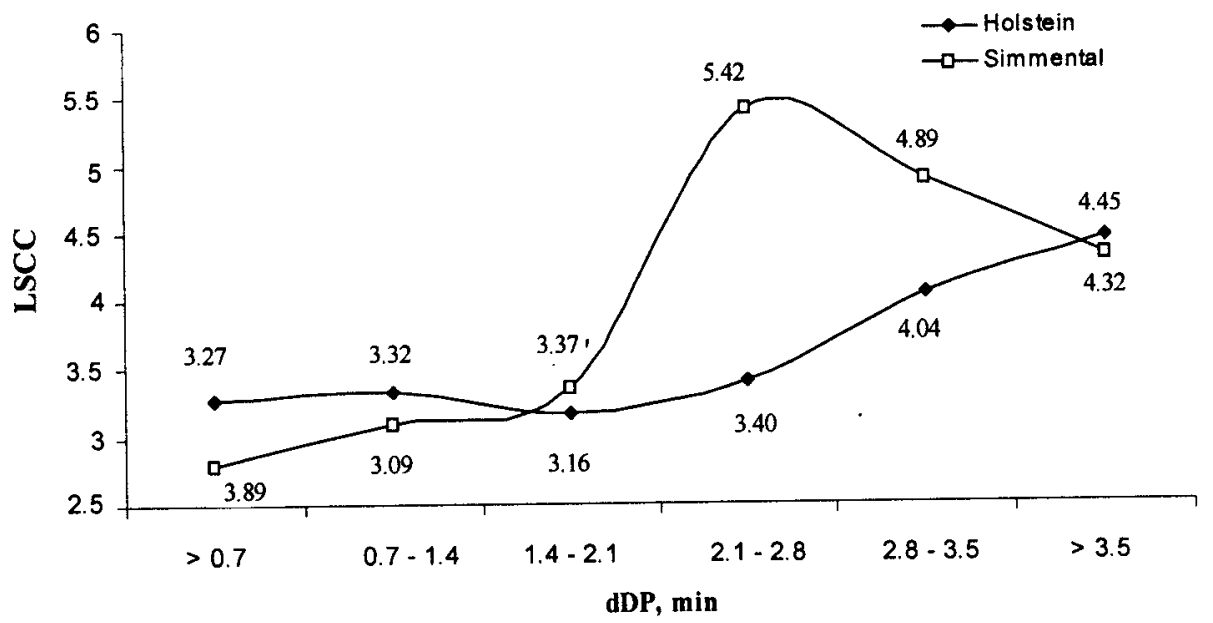

Figure 3. Relations between duration of decreasing phase (dDP) and somatic cell count (LSCC) in Holstein and Simmental cows

The correlations between dIP and LSCC in both breeds were insignificant (Table 2). A slightly greater correlation was found between dPP and LSCC $(r=-0.255$ and -0.184$)$, where significance was determined in Holstein cows $(\mathrm{P}<0.01)$. The correlation between $\mathrm{dDP}$ and LSCC in Holstein cows was weak and negative, while that of the Simmental cows showed significance $(\mathrm{P}<0.05)$. 
Another significant negative correlation was observed between dMP and LSCC $(\mathrm{P}<0.01)$ in Holstein cows.

TABLE 2

Correlations ( $\mathrm{rp}$ ) between linear score of somatic cell count (LSCC) and milking rate parameters

\begin{tabular}{llllll}
\hline \multirow{2}{*}{ Parameters } & \multicolumn{2}{c}{ Holstein } & & \multicolumn{2}{c}{ Simmental } \\
\cline { 2 - 3 } \cline { 5 - 6 } & LSCC & SCC & & LSCC & SCC \\
\hline dIP & 0.045 & 0.011 & & -0.072 & -0.087 \\
dPP & $-0.255^{* *}$ & $-0.145^{* *}$ & & -0.200 & -0.184 \\
dDP & -0.025 & -0.011 & & $-0.322^{*}$ & $-0.343^{* *}$ \\
dMP & $-0.195^{* *}$ & $-0.105^{*}$ & & 0.118 & 0.140 \\
\hline
\end{tabular}

** $\mathrm{P}<0.01 ; * \mathrm{P}<0.05$

\section{DISCUSSION}

A link between the milking characteristics and udder health lies in the physical connection of the udder anatomy and the resistance to infection. Up to now, research has shown that somatic cell counts in milk grow with the shortening of the milking period, and too slow or too fast milk flows (Roth et al., 1998). Therefore, the selection service should recommend the selection of cattle with an optimal milk flow which in turn would benefit the udder health (Mijić et al., 2003).

Shortening the $\mathrm{dDP}$ by prolonging the $\mathrm{dPP}$ could have an effect on balancing of the udder quarters. By doing this, the milking process would shorten, and the amount and flow of milk would be balanced out between the quarters more equally. The plateau phase should last 4 to $4.5 \mathrm{~min}$, while the releasing phase should last under 1 min (Göft et al., 1994). In that case, the duration of the main milking phase would last for less than 6 min, which correlates with the duration of oxytocin release. The smallest LSCC was observed when dDP lasted less than $0.8 \mathrm{~min}$ and the quotient between $\mathrm{dPP}$ and dDP was greater than 1.8 (Naumann et al., 1998). Therefore, the longer dPP, keeping dDP short, the lower the somatic cell count, and in turn, the healthier the udder. For this reason Sprengel et al. (2001) point out that the selection for the longer dPP, without the shortening of dDP is not acceptable. The same conclusions can be drawn from the results of our research presented in Figures 2 and 3, where the somatic cell count was lowered by prolonging of dPP and shortening of dDP. As shown in Figure 1, the udder could also suffer damage if milk is too fast being released in the moment of putting-on the teat cups (increasin milk flow). The damage could manifest itself as the weakening of the sphincter muscle on the tip of the nipple (Roth et al., 1998), a condition that benefits the entry of microorganisms into the udder. Similar 
observations were made by Bolgov et al. (2002), who stated that besides factors such as age, production level and season of lactation, the occurrence of mastitis also depends on the udder characteristics. That mastitis is a great enemy of the dairy industry was shown by a research performed in Poland (Fandrejewska, 1993) during which it was shown that over $65.5 \%$ of milk samples collected at 77 dairy farms were infected with pathogenic microorganisms.

The correlation coefficients, shown in Table 2, point to the possibility of selection for certain phases of milk flow. This is especially true for dPP. By prolonging this phase, the udder quarters would be more evened out, avoiding the irritation caused by prolonged machine milking. The milking machine would do the do the job simultaneously and even, whereby dDP would be very short. Dodenhoff et al. (1999) determined slightly lower values of the correlation coefficient between dPP and SCC for the Holstein breed of cows $\left(r_{p}=-0.16\right)$ than the one determined in our study. However, Sprengel et al. (2001) have also proven the existence of a negative correlation between above mentioned parameters in their study performed on 1.7 million cows in Germany. This negative correlation could be used successfully for selection purposes.

\section{CONCLUSIONS}

Research has shown that there is a possibility for improvement of milking characteristics and health aspects in dairy cattle through selection. Cows should be selected on the basis of their milking characteristics, favouring ones with a relatively fast dIP and long dPP, whereby $\mathrm{dPP}$ is increased through the shortening of dDP of the milk flow. The speed of achievement of our selection goals will depend on the direction of the production plan. For this reason it is imperative to include the milking characteristics as criteria for the selection process as soon as possible. Selection should be aimed at bull's dams and sires, and later on be extended to include the rest of the population.

\section{REFERENCES}

ADR - Arbeitsgemeinschaft Deutscher Rinderzüchter, 1987. The According 3.3 to Performance of Milkability Investigation (in German). Bonn RL 3.3, Stand 4, 3.1-3.3

Boettcher P.J., Dekkers J.C.M., Kolstad B.W., 1998. Development of an udder health index for sire selection based on somatic cell score, udder conformation, and milking speed. J. Dairy Sci. 81, 1157-1168

Bolgov A.E., Karmanova E.P., Muravja L.N., Makarova V.E., Shterkel S.G., Grishina N.V., 2002. The influence of different factors on resistance of dairy cows to mastitis. J. Anim. Feed Sci. 11, 237-254 
Dodenhoff J., Sprengel D., Duda J., Dempfle L., 1999. Studies on genetic evaluation of udder helth using the LactoCorder (in German), Züchtungskunde 71, 459-472

Fandrejewska M., 1993. Somatic cell count in quarter foremilk of cows from small herds with a high level of subclinical mastitis. J. Anim. Feed Sci. 2, 15-26

Göft H., Duda J., Dethlefsen A., Worstorff H., 1994. Studies on breeding use of milkability traits with regard to milk flow curves in dairy cattle (in German). Züchtungskunde 66, 23-37

Mijić P., Knežević I., Baban M., Domaćinović M., 2003. Relationship of milking rate and somatic cell count to the health of bovine udders. Milchwissenschaft 58, 119-121

Naumann I., Fahr R.D., Lergerken G., 1998. Relationship between somatic cell count of milk and special parameters of milk flow curves of cows (in German). Arch. Tierzucht 41, 237-250

Roth S., Reinsch N., Nieland G., Schallenberger E., 1998. Interrelationships between udder health, milkability characteristics and milk flow curves in a high yielding dairy herd (in German). Züchtungskunde 70, 242-260

Sprengel D., Dodenhoff J., Duda J., Götz K.U., Dempfle L., 2001. International genetic evaluation for milkability. Interbull Bull. 27, 35-40

StatSoft, Inc., 2003. STATISTICA (data analysis software system), Version 6. www.statsoft.com

\section{STRESZCZENIE}

Zależność pomiędzy różnymi fazami wypływu mleka przy doju mechanicznym a liczbą komórek somatycznych w mleku

Dla utrzymania dobrego stanu zdrowia wymienia krów dojonych mechanicznie jest ważne, aby czas doju był krótki, a optymalny wypływ mleka następował możliwie szybko i możliwie długo utrzymywał się na tym samym poziomie.

Stwierdzono, że liczba komórek somatycznych (SCC) w mleku krów rasy holsztyńskiej ( $\mathrm{LSCC}=3,03$ ) była najniższa przy długości fazy wpływu mleka wzrastającej od 0,3 do 0,6 min, zaś u simentali (LSCC $=2,96$ ) od 0,6 do 0,9 min. Przedłużanie fazy plateau (dPP) miało korzystny wpływ na stan zdrowia wymienia u obydwóch ras $(\mathrm{LSCC}=2,46$ i 2,50$)$. dPP powinno być wydłużone przez skrócenie czasu fazy wzrastającego wypływu mleka, ponieważ najmniejszą liczbę komórek somatycznych w mleku (LSCC=3, 27 i 2,50) stwierdzono wówczas, gdy dPP było krótsze niż 0,7 minuty. 